\title{
Posílení role nezletilého v řízeních péče soudu o nezletilé*
}

\section{Strengthening The Minor's Role in Child Care Proceedings}

\author{
Sabina Čamdžićovát*
}

\begin{abstract}
Abstrakt
Tento článek se vènuje možnostem plnohodnotnébo zapojeni ditète do rǐzeni, které se ho dotýké, tj. zejména ř̈zeni ve vècech péce soudu o nezletilé, ve kterých se rozhoduje o üpravě pomèru tohoto ditéte. V takových

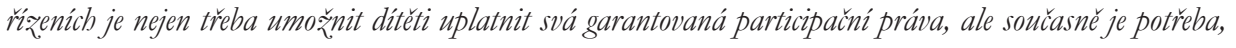
aby rízeni predstavovalo rychlý, efektivni proces, který bude chránit jednak, práva ditète, ale také rodinný żivot jako takový, protože je tréba, aby stát prostrédnictvím nezávislých soudì chránil práva dítète v aktuální chvíli, ale také predevšim do budoucna tak, aby rodinná situace kolem ditète byla stabilizována. Jednou z. možných cest jak vést takové rízeni, je aplikovat principy interdisciplinárni spolupráce a také zajistit úcinné zastoupeni nezletilého, které mu lépe umožni využit svá participačni práva.
\end{abstract}

\section{Klíčová slova}

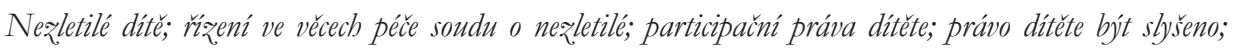
kolizni opatrouník; interdisciplinární spolupráce.

\begin{abstract}
This article discusses the possibilities of full involvement of the child in the proceedings that concerns him or her, above all in the proceedings abou the childs care, in which is decided about future of this child. In such proceedings, it is not only necessary to allow the child to exercise his or her guaranteed participation rights, but at the same time it needs to be a rapid, effective process that will protect not only the rights of the child but also family life as well, because the state has to protect through independent courts the rights of the child not only at the moment, but above all in the future so that the family situation around the child is stabilized. One of the possible ways to lead such a process is to apply the principles of interdisciplinary cooperation and also to ensure effective representation of the minor, which will also belp child to use its participation rights.
\end{abstract}

\section{Keywords}

Child; Juvenile; Child Care Proceedings; Child's Participation Rights; Child's Right to be Heard; Collisional Guardian; Interdisciplinary Cooperation.

\footnotetext{
* Tento článek vznikl za podpory prostředků poskytnutých studentskou grantovou soutěží Univerzity Palackého v Olomouci IGA Právnická fakulta 2017 „Ochrana dítěte v civilním řízeni““ č. projektu IGA_PF_2017_022.

** Mgr. Sabina Čamdžićová, doktorandka, Katedra soukromého práva a civilního procesu, Právnická fakulta, Univerzita Palackého v Olomouci / Department of Private Law and Civil Procedure, Faculty of Law, Palacký University in Olomouc, Czech Republic / E-mail: sabina.camdzicova01@upol.cz
} 


\section{Úvod}

Otázka role a postavení nezletilého dítěte $\mathrm{v}$ civilním řízení je $\mathrm{v}$ posledních letech velmi aktuálním a často skloňovaným tématem, zejména hovoříme-li o otázce participačních práv, která mají být dítěti v každém řízení, které se jej týká, garantována. Souvisí se změnami ve společnosti, a to jak společenskými, tak politickými. Spolu s rostoucím počtem rozvodů manželství a rozpadů vztahů nesezdaných rodičů dítěte se zvyšuje také počet rrízení ve věcech péče soudu o nezletilé, ve kterých je potřeba upravit poměry dítěte pro dobu po rozvodu. V řízeních péče soudu o nezletilé je proto potřeba systematicky posilovat roli dítěte, když právě jeho práva a povinnosti mají být dotčena. Bohužel stále ne každý soudce na dítě nahlíží jako na účastníka řízení, kterému náleží všechna procesní práva a povinnosti, a v jehož zájmu není být za každou cenu chráněno před kontaktem s justicí. Občas je zapomínáno na to, že řízení ve věcech úpravy poměrů dítěte není sporem mezi rodiči, nýbrž že předmětem takového řízení je hledání nejlepšího zájmu dítěte. Otázka práva dítěte participovat na ř́zení, které se ho týká, vyvstala také v souvislosti s politickými změnami ve společnosti. Ačkoli nejde o zcela aktuální záležitost, tak jsem přesvědčena, že socialistická minulost se bohužel v právním řádu a myšlení osob aplikujících právní předpisy promítá dodnes. Za minulého režimu panovalo přesvědčení, že výchova dětí je otázkou veřejného zájmu, což zakotvoval i zákon č. 94/1963 Sb., o rodině, ve svém původním znění ${ }^{1}$, kdy např́klad v \30 stanovil, že na výchově dítěte se v nerozlučné jednotě podílejí rodiče, stát a společenské organizace. Předním výchovným úkolem pak bylo působit na citový, rozumový a mravní vývoj dětí v duchu zásad morálky socialistické společnosti ( $\left.\int 31\right)$. Zajistit participační práva dětí v řízení v tomto kontextu tak nebylo podstatné, nebot' to byl stát, potažmo socialistická společnost, kdo „v duchu socialistické morálky" určoval, co je pro dítě vhodné. Obrovský vliv státu na soukromý život jednotlivců, a to nejen pokud jde o rodinné právo, se pak bohužel projevil ve společnosti $\mathrm{v}$ mnoha směrech (které nejsou předmětem toho článku) a jedním z nich byl dle mého názoru právě i ten, že dětem nebyla přiznávána možnost rozhodovat samostatně o svém životě, nebot' od toho zde byli dospělí, společnost a stát. Myšlenka, že dospělí vždy vědí lépe, co je pro dítě dobré, v mnohém přetrvala do dnešní doby. $\mathrm{V}$ mnoha směrech samožrejmě není pochyb o tom, že to mají být primárně rodiče, kdo budou za dítě rozhodovat zásadní otázky. Na druhou stranu, jak velmi trefně poznamenala Kateřina Šimáčková ${ }^{2}$ - i děti jsou plnohodnotné lidské bytosti, a je nezbytné jim dát přiměřenou možnost rozhodovat o svém životě. A právě systematické posilování role dítěte $\mathrm{v}$ řízeních, jež se ho týkají, je jeden z velmi důležitých prostředků.

1 Znění účinné k 1. 4. 1964.

2 Při přednesu svého příspěvku v plenární sekci konference Olomoucký den soukromého práva pořádané Právnickou fakultou Univerzity Palackého v Olomouci dne 8. 2. 2019. 
Pokud jde o posilování role nezletilého dítěte v ř́izení, nejde pak samozřejmě jen o důsledné přiznávání participačních práv tomuto dítěti, nýbrž o celkové pojetí těchto řízení. Jak bylo již řečeno, půjde nejčastěji o rrízení ve věcech péče soudu o nezletilé související s rozpadem vztahů rodičů, a proto se i v tomto článku budu věnovat právě těmto řízením. Rízení by měla být vedena efektivně, a to tak, aby byla poskytována ochrana nejen dítěti jako takovému, ale obecně aby byla chráněna rodina a rodinný život, protože v zájmu nezletilého bude vždy žít ve fungujícím rodinném prostředí, kdy rodiče jsou schopni jednat ve vzájemné souhře a nepoužívají dítě jako nástroj řešení vlastních frustrací vůči bývalému partnerovi. A i toto by mělo být v řízeních péče soudu o nezletilé zohledněno. Soud proto vede rodiče primárně ke smírnému vyřešení věci. Je-li to potřeba, může soud rodičům uložit účast na mimosoudním smírčím nebo mediačním jednání nebo rodinné terapii, nebo jim nařídit setkání s poskytovatelem odborné pomoci, zejména odborníkem v oboru pedopsychologie (\ 474 odst. 2 zákona č. 299/2013 Sb., o zvláštních řízeních soudních, ve znění pozdějších předpisů, dále jen „ZŘR“).

Bohužel však jsou př́pady, kdy se rodiče dítěte nejsou schopni dohodnout na budoucím uspořádání péče o dítě, pravidlech styku rodiče s dítětem a dalších souvisejících otázkách. Samotný rozpad vztahu rodičů je pro děti nepochybně traumatickou událostí v životě. Následuje-li po něm soudní řízení ve věci péče soudu o toto nezletilé dítě, je nezbytné zajistit, aby se nejednalo o zdlouhavý neefektivní proces. Pravidla a postupy v takovém rrízení by měly být nastaveny tak, aby představovaly pro dítě co nejmenší zátěž, při současném zachování práva dítěte se takového řízení účastnit, a to v rozsahu přiměřeném jeho věku a rozumové vyspělosti. Tendencí poslední doby je v této souvislosti zdůrazňovat roli dítěte, jako subjektu práv v řízení, nikoli pouhého objektu, o kterém se v řízení jedná. Jinými slovy řečeno, řízení by nemělo ve vztahu k dítěti probíhat tak zvaně „o nás, bez nás“.

\section{Dítě v rodičovském konfliktu}

Rodičovské konflikty vznikají obvykle v situaci, kdy by rodiče měli vyřešit otázky týkající se jejich společného dítěte (dětî) v souvislosti s rozpadem jejich vztahu, at’ už rozvodem nebo rozchodem v prrípadě, že nebyli manželé. Rodiče by se pak měli primárně dohodnout, s kým bude dítě žít ve společné domácnosti, tedy na otázce, komu má být dítě svěřeno do osobní péče, na tom, jakým způsobem bude upraven styk dítěte s druhým rodičem - tedy kdy a jak často se má nerezidentní ${ }^{3}$ rodič právo s dítětem stýkat a samožrejmě také na výši výživného pro dítě. Pokud jsou rodiče dítěte manželé, musí vždy být poměry nezletilých dětí upraveny soudním rozhodnutím (『906 odst. 1 zákona č. 89/2012 Sb., občanský zákoník, ve znění pozdějších předpisů, dále jen jako „OZ“). V souladu s \ 908 OZ se nesezdaní rodiče mohou na budoucím uspořádání péče o dítě

3 Tj. ten rodič, kterému není dítě svěřeno do výlučné osobní péče. 
a dalších otázkách dohodnout, aniž by ve věci musel obligatorně rozhodnout soud. I nesezdaní rodiče mohou požádat soud, aby jejich dohodu o úpravě poměrů nezletilého dítěte svým rozhodnutím schválil. Soud dohodu rodičů svým rozsudkem schválí, pokud dospěje k závěru, že její obsah je v souladu se zájmy dítěte \ 908 druhá věta). V opačném př́padě může soud dohodu neschválit a upravit poměry nezletilého dítěte dle svého uvážení. Pokud se rodiče nedohodnou vůbec, což může být z důvodu nefunkční komunikace anebo i proto, že třeba nevědí, jaké možnosti dohody existuji ${ }^{4}$, rozhodne o péči o dítě opět soud (\$ 908 OZ).

V obou případech může být soudní řízení o úpravě poměrů dítěte fakticky velmi krátké, a to v př́padech, kdy soud „pouze“ schvaluje dohodu rodičů. Dohoda rodičů však musí vždy odpovídat nejlepším zájmům dítěte, a soud může dohodu schválit, pouze pokud taková dohoda zjevně neodporuje nejlepšímu zájmu dítěte (『906 odst. 2 OZ, 『908 druhá věta).

$\mathrm{Na}$ tomto místě bych ráda uvedla několik statistických informací, které ve svém článku shrnula Romana Rogalewiczová5, když uvádí, že ,približně 60-70 \% roz̧cházejicich se rodiču je schopno se na dalši úpravě životni situace svých dètí bez vážnèjšich problému domluvit,

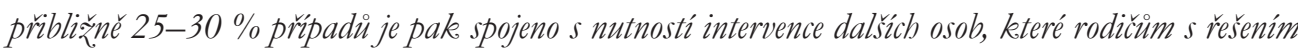
jejich situace pomáhaji (ty to prípady pak konči bud' dohodou rodiču po delš době a s využitím podpory některé z.pomáhajicich profesi, nebo autoritativním rozhodnutím soudu, které je v̌sak ze strany rodiču respektováno). Zbývajicich 3-5\% prípadu je pak razeno mezi natolik quávažné, že jsou prakticky

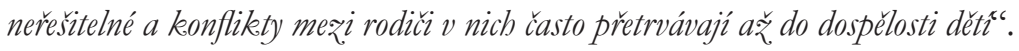

Ze statistik okresních soudů České republiky za roky 2015-20176 zveřejněných na portálu Ministerstva spravedlnosti České republiky justice.cz pak vyplývá, že soudy rozhodují ročně téměr 40000 případů týkajících se úpravy poměrů nezletilého dítěte ${ }^{7}$ Pro zajímavost např́iklad v roce 2010 to bylo „pouze“ 30000 případů. Pokud bychom na tato čísla aplikovali výše uvedenou statistiku, dalo by se velmi zjednodušeně a přibližně říci, že ročně se potýká na 10000 rodičů s konfliktem, ve kterém se nejsou bez cizí pomoci schopni dohodnout na budoucím uspořádání života jejich společného dítěte.

Z výše uvedeného tak nepochybně vyplývá, že řízení ve věcech péče soudu o nezletilé se týkají poměrně velkého počtu dětí. Účast v soudním řízení může však pro dítě znamenat obrovský stres až trauma, umocněný samotnou emocionálně náročnou situací v rodině. Rízení ve věcech péče soudu o nezletilé je proto potřeba vést takovým způsobem, aby pro dítě představovala pokud možno co nejmenší zátěž.

4 POLÁK, Vladimír a Lenka WESTPHALOVÁ. Interdisciplinární spolupráce ve věcech péče soudu o nezletilé. Právní roz̧bledy, 2018, roč. 25, č. 7, s. 240-248.

5 ROGALEWICZOVÁ, Romana. Interdisciplinární spolupráce při řešení rodičovských konfliktů. Bulletin advokacie, 2017, roč. 23 , č. 12, s. 35.

6 Statistiky dostupné z: https://cslav.justice.cz/InfoData/prehledy-statistickych-listu.html [cit. 12. 1. 2019].

7 Jedná se jak o př́pady úpravy péče po rozvodu manželství, tak o prrípady nesezdaných rodičů. 
Rízení ve věcech péče soudu o nezletilé je potřeba v každém případě vést tak, aby stres jím způsobený muselo dítě snášet co nejkratší dobu . Jediným a výhradním předmětem takových řízení by mělo být hledání řešení poměrů v rodině, které bude v nejlepším zájmu dítěte. Výbor OSN pro práva dítěte ${ }^{9}$ vymezuje obsah nejlepšího zájmu dítěte jako právo na celostní rozvoj a plné a účinné poživání všech práv garantovaných Úmluvou ${ }^{10}$, přičemž druhá část této definice pak jinými slovy říká, že každému dítěti mají být v plném rozsahu zaručena Úmluvou garantovaná práva. A to jak práva procesního, tak práva osobního charakteru. Každé dítě by tak mělo mít mimo jiné možnost vyrůstat v péči obou svých rodičů, kteří by měli zajistit potřeby dítěte, pokud jde o citové rodinné vazby a bezpečí, ochranu jeho života, zdraví i př́iznivého vývoje. ${ }^{11}$

\section{Právo dítěte být slyšeno}

Úmluva dítěti garantuje samožrejmě také práva procesního charakteru, z nichž za nejdůležitější v kontextu tohoto článku považuji právo dítěte být slyšeno. Podle čl. 12 odst. 1 Úmluvy musí stát zabezpečit dítěti, které je schopno formulovat své vlastní názory, právo tyto názory svobodně vyjadřovat ve všech záležitostech, které se jej dotýkají, přičemž se názorům dítěte musí věnovat patřičná pozornost odpovídající jeho věku a vyspělosti. Toto právo má být realizováno zejména poskytnutím možnosti být slyšeno v každém soudním nebo správním řízení, které se jej dotýká, a to bud’ prímým slyšením dítěte anebo prostřednictvím zástupce nebo příslušeného orgánu, vše v souladu s vnitrostátními procesními předpisy (čl. 12 odst. 2 Úmluvy). Zákonný rámec práva dítěte být slyšeno v českém civilním soudním řízení představují \ 100 odst. 3 zákona č. 99/1963 Sb., občanský soudní řád, ve znění pozdějších předpisů (dále jen ,OŠ̌"), 』 20 odst. 4 ZǨS a $\int 867$ OZ.

Při rozhodování o tom, jak mají být upraveny poměry, by mělo být dítěti vždy, pokud je to možné, umožněno vyjádřit svou představu o budoucím uspořádání a jeho názor by měl být pokud možno respektován. Je však na soudu, aby vyhodnotil názor dítěte v kontextu dalších okolností, a na základě toho rozhodnul. Názor dítěte totiž může být mnohdy ovlivněn rodičem, který má rozhodující vliv na výchovu dítěte. Zájem dítěte tudíž nelze vykládat jako akceptaci jejich stanoviska ${ }^{12}$. Je totiž třeba mít vždy na paměti,

8 ROGALEWICZOVÁ, Romana. Interdisciplinární spolupráce při řešení rodičovských konfliktů. Bulletin advokacie, 2017, roč. 23, č. 12, s. 35 .

9 Komentář Výboru OSN pro práva dítěte ze dne 29. 5. 2013. Plný text dostupný z: http:/ / tbinternet.ohchr. org/_layouts/treatybodyexternal/Download.aspx?symbolno $=\mathrm{CRC} \% 2 \mathrm{fC} \% 2 \mathrm{fGC} \% 2 \mathrm{f} 14$ \& Lang $=\mathrm{env}$ [cit. 15. 1. 2019].

10 HOFSCHNEIDEROVÁ, Anna. Praktický právnípriovodce nejlepsím zájmem dítète. Pro pracovníky orgánu sociálně právní ochrany dětí. 1. vyd. Brno: Liga lidských práv, 2016, s. 8-9.

11 Ibid.

12 K tomu srov. např. Nález Ústavního soudu ze dne 10. 5. 2006, sp. zn. IV. ÚS 288/04. 
že dítě není ještě plně rozumově vyspělé a rozchod rodičů pro něj znamená obrovskou emoční zátěž. K tomu se vyjádřil také veřejný ochránce práv, když uvádí, že „citová povahová nevyrounanost $v$ době dospiváni mưže být faktorem, který čni hodnotu jejich výpovédi zucela nevěrohodnou. Je v̌̌dy potreba mit na paměti, že dítè je korumpovatelné (během výchovného procesu si ditě musi osvojit radu návykü, radu povinností, musi vyspivat morálnè, respektovat hranice, pravidla, normy, drubé osoby apod.) a vydiratelné (bèhem procesu svébo citového vyspiváni a zráni je díté zvýšenè divvérvvé, sugestibilni, zapálené pro spravedlnost, zranitelné a i bezbranné viòi citovému vydíráni, keteré samozrejejmé ani neproblédne) ${ }^{* 13}$. Toto je pak plně použitelné při posuzování názoru nezletilého $\mathrm{v}$ řízeních péče soudu o nezletilé, protože dítě může být například ovlivňováno jedním z rodičů, mít strach, že některému z rodičů svým názorem ublíží apod. Ústavní soud se pak také věnoval otázce samotného zjišt'ování názoru dítěte a konstatoval, že je potřeba tak učinit komplexně, zejména prostřednictvím nepřímých otázek, a to nejlépe $\mathrm{v}$ neformálním prostředí (nap̌r. v kanceláři soudce namísto v soudní síni). Ústavní soud připomněl, že je nutné vyvarovat se zavádějících otázek typu „U koho bys chtěl/a bydlet? "14. Samozřejmostí by pak mělo být, že se dítěti umožní vyjádřit se bez př́tomnosti rodičů. Přání dítěte by mělo být vždy základním vodítkem, jak pro rodiče př́i uzavírání dohody, tak pro soud při rozhodování. Pokud mu není vyhověno, je potřeba dítěti náležitě vysvětlit, z jakého důvodu se tak stalo.

Pokud je dítě účastníkem je s ohledem na jeho neúplnou rozumovou vyspělost potřeba tomu přizpo̊sobit způsob vedení takového řízení. Kromě toho, že musí být dítěti poskytnut dostatečný prostor k vlastnímu vyjádření, pokud o to dítě stojí a je na to dostatečně zralé, je potřeba respektovat dětskou osobnost i v dalších ohledech. Z tohoto důvodu přijal Výbor ministrů Rady Evropy v r. 2010 Pokyny o justici vstřícné k dětem (dále jen „Pokyny“). Jde o soubor pravidel, která by měla být dodržována v řízeních, v nichž vystupuje dítě, at’ už v jakémkoli postavení. Pokyny vycházejí z premisy, že dítě jako subjekt, který se ještě vyvijí, dotváří svou osobnost, je stále v procesu rozumového, volního a mravního vývoje, vyžaduje zvláštní př́istup a zacházení, pokud se dostane do kontaktu se státními orgány (bez ohledu na to, zda se jedná o soudní orgány, správní orgány, nebo orgány činné $v$ trestním řízenî ${ }^{15}$. Dítěti je třeba v této souvislosti zajistit jeho základnî práva $\mathrm{v}$ ř́izení, rovný prístup $\mathrm{k}$ informacím, které mu musí být poskytovány úměrně k jeho věku a možnostem chápat situaci a celkové souvislosti. Dítě se v řízení musí cítit bezpečně a nemělo by nabýt dojmu, že je pouhým objektem, o kterém rozhodují dospělí.

13 MOTEJL, Otakar a kol. Sborník stanovisek verejného ochránce práv. Rodina a dítě. Brno: Kancelář veřejného ochránce práv, 2007, s. 63.

14 Nález Ústavního soudu ze dne 26. 5. 2014, sp. zn. I. ÚS 2482/13.

15 ROGALEWICZOVÁ, Romana. Možnosti aktivního zapojení dítěte do řízení. Prární roz̧hledy, 2018, roč. 25 , č. 8 , s. 267. 
Koncept Justice vstřícné $\mathrm{k}$ dětem má představovat systém, který garantuje respekt k právům dítěte a efektivní implementaci všech práv dítěte, a to na nejvyšší možné úrovni ${ }^{16}$. Justice musí fungovat tak, aby se děti nedostaly pouze do vleku událostí probíhajícího procesu, aniž by rozuměly jeho podstatě, průběhu, důvodům, proč k ř́izení došlo a proč dochází $\mathrm{k}$ jednotlivým úkonům, $\mathrm{v}$ jakém pořadí a $\mathrm{v}$ jaké podobě ${ }^{17}$. Justice má přizpůsobit své tempo dětem: není uspěchaná ani vleklá, ale je přiměřeně rychlá ${ }^{18}$. Pro dítě je nejlepší, aby po celou dobu řízení bylo průběžně informováno o dění, proč dochází k jednotlivým úkonům, jak probíhají, jaký je jejich cíl, co pro dítě která část řízení znamená, jaká má dítě práva a naopak jaké jsou jeho povinnosti v řízení ${ }^{19}$. Pokyny pak také stanoví, že by měly být odstraněny překážky př́istupu dítěte k justici, zejména pokud jde o poplatky anebo chybějící zajištění zastoupení nezletilého ${ }^{20}$.

\section{Zastoupení nezletilého}

Pokyny o justici vstřícné $\mathrm{k}$ dětem kladou dưraz na právo dítěte být slyšeno a jeho realizaci s ohledem na věk dítěte ${ }^{21}$. Dle důvodové zprávy $\mathrm{k}$ Pokynům se pak dítě při svém slyšení má cítit bezpečně a uvolněně, a to i za cenu, že bude potřeba upustit od některých běžných formalit. Soudce se může s nezletilým setkat mimo jednací místnost, nemusí na sobě mít talár apod. Dítě má mít na výběr, jakým způsobem chce svưj názor sdělit, zda chce mluvit prímo se soudcem, nebo raději zprostředkovaně, tedy s pracovníkem orgánu sociálně právní ochrany dětí (dále jen „OSPOD“), soudním znalcem, nebo svým procesním zástupcem, kteří jeho názor následně sdělí soudci. Po ukončení rúzení má být dítě srozumitelně seznámeno s jeho výsledkem a důsledky, které pro ně přijaté rozhodnutí bude mít ${ }^{22}$.

Body 37 až 43 pokynů se pak věnují otázce zastoupení dítěte v soudním řízení. Pokyny stanoví, že děti by měly mít právo na svého vlastního právního zástupce a zastoupení svým vlastním jménem v řízeních, $v$ nichž nastal nebo by mohl nastat střet zájmů mezi dítětem a rodiči nebo jinými zúčastněnými stranami. Děti by pak také měly mít právo na př́stup $\mathrm{k}$ bezplatné právní pomoci nejméně za stejných podmínek jako dospělí.

16 PINHEIRO, Sergio Paulo. Reflections on Child-friendly Justice. In: MAHMOUDI, Said, Pernila LEVINER, Anna KALDAL a Katrin LAINPELTO (eds.). Child-friendly Justice. A Quarter of a Century of the UN Convention on the Rights of Child. 1. vyd. Leiden (Nizozemî): Koninklijke Brill NV, 2015, s. 27.

17 WESTPHALOVÁ, Lenka a Romana ROGALEWICZOVÁ. Práva dítěte v rodičovském konfliktu. Právní rozhledy, 2016, roč. 23, č. 19, s. 660.

18 Pokyny výboru ministrü Rady Evropy o justici vstř́cné k dètem, s. 8. Dostupné z: https://rm.coe.int/16804ba0fb

19 WESTPHALOVÁ, Lenka a Romana ROGALEWICZOVÁ. Práva dítěte v rodičovském konfliktu. Právni roz̧ledy, 2016, roč. 23, č. 19, s. 660.

20 Srov. bod 35 Pokynů.

21 Srov. body 44-49 Pokynů.

22 ROGALEWICZOVÁ, Romana. Možnosti aktivního zapojení dítěte do řízení. Právní roz̧bledy, 2018, roč. 25 , č. 8 , s. 267. 
Zástupci dítěte by si pak měli osvojit dostatečné kompetence práce s dítětem, tzn., měli by pravidelně absolvovat různá školení apod., aby byli schopni s dětmi komunikovat a porozumět jim.

Pokyny tedy kladou důraz na účinné zastoupení nezletilého v řízeních, kde může hrozit kolize jeho zájmů se zájmy zákonných zástupců, což bude v řízeních péče soudu o nezletilé nastávat téměř vždy. V české právní úpravě pak platí ust. \469 odst. 1 Ž̌S, kdy toto stanoví, že dítě je v řízení zastoupeno opatrovníkem, kterého soud pro řízení jmenuje. Opatrovníkem soud jmenuje zpravidla orgán sociálně-právní ochrany dětí (dále také jen „OSPOD“). Podle odst. 2 citovaného ustanovení nemůže plnit roli opatrovníka téže orgán sociálně právní ochrany dětí, který podal návrh na zahájení řízení. I v takovém př́padě je však možné jmenovat kolizním opatrovníkem jiný OSPOD, tudíž orgán téže větve veřejné moci, řízený stejnými interními instrukcemi apod.

Kladu si však otázku, zda je vưbec vhodné, aby OSPOD kdykoli vystupoval v roli zástupce dítěte jakožto veřejný opatrovník. Jsem přesvědčena, že vhodnějším řešením by bylo zavedení nové procesní funkce kolizního opatrovníka dítěte, jehož jediným úkolem by bylo právě zastupování nezletilého v soudním řízením. Dítěti je s ohledem na jeho neúplnou rozumovou a volní vyspělost potřeba zajistit takového zástupce, který bude schopen s ním individuálně pracovat, probrat s ním v souladu s výše uvedeným, co se v řízení aktuálně děje, vysvětlit mu jeho možnosti a práva, zjistit skutečný názor dítěte a ten následně interpretovat. $\mathrm{K}$ účinnému zastoupení je také nezbytné vytvoření určité důvěry mezi dítětem a jeho zástupcem.

Úkolem OSPOD je navíc také práce s rodinou jako takovou, tudíž i s rodiči dítěte, ve snaze deeskalovat prrípadný konflikt a zajistit ochranu dítěte. Dochází proto k souběhu více rolí a úkolů, často v osobě jedné úřednice. Hrozí proto, že dítě nebude se sociálním pracovníkem chtít jednat ve strachu, že jeho názor sdělí rodičům (resp. jednomu z nich). S ohledem na vytížení OSPOD není také možné požadovat po úřednících OSPOD skutečně dostatečnou a individuální péči o každé jednotlivé dítě, nebot' na to bohužel nemajî kapacity. Mám proto za to, že by bylo vhodné zamyslet se nad systémovou změnou pojetí zastoupení nezletilého, kdy prvním krokem by mělo být omezení úkolů OSPOD pouze na práci s rodinou, šetření na místě apod. a funkce veřejného opatrovníka by mu měla být odejmuta. Dojde tím mimo jiné i ke zvětšení časových možností pracovníků OSPOD. Jelikož bude vždy v zájmu nezletilého dítěte obnovit funkční rodinné prostředí, měl by být pracovníkům OSPOD dán prostor věnovat se důsledně rodinám, které potřebujî pomoc. Pomoc OSPOD může spočívat v odstraňování výchovných problémů, v různé metodické pomoci, $\mathrm{v}$ pomoci rodičům zajistit dostatečně bytové potřeby apod. Takto by OSPOD naplňoval úkoly mu svěřené \ 1 odst. 1 zákona č. 359/1999 Sb., o sociálně právní ochraně dětí, ve znění pozdějších předpisů.

OSPOD by se i nadále měl účastnit řízení ve věcech péče soudu o nezletilé, kde by měl chránit veřejný zájem na řádné péči o dítě a jeho výchově. OSPOD by např́iklad měl 
podávat soudu zprávy z místního šetření v rodině či ve školním zařízení, které dítě navštěvuje. OSPOD by měl pomáhat soudu nalézt vhodné uspořádání budoucích poměrů dítěte, tak aby byly chráněny nejlepší zájmy dítěte.

Pokud pak jde o samotné změny v kolizním opatrovnictví dětí, tak by možnou inspirací mohla být německá právní úprava, kdy podle \158 zákona německého zákona o řízeních ve věcech rodinněprávních a $\mathrm{v}$ záležitostech nesporného soudnictví23 může soud dítěti jmenovat opatrovníka - pomocníka v řízení ${ }^{24,25}$, který by měl mít právní nebo psychologické vzdělání a v řízení má jedinou roli, a sice pomáhat dítěti v ř́izení26

Podobné pojetí zastoupení nezletilého dítěte v soudním rrízení zastává také australský právní řád ${ }^{27}$. V rodinněprávním řízení může soudce ze své iniciativy, př́ípadně k návrhu k tomu oprávněných osob, nezletilému dítěti ustanovit (na všech procesních stranách) nezávislého právního zástupce ${ }^{28,29}$. Úkolem nezávislého právního zástupce dítěte je chránit nejlepší zájmy dítěte, informovat dítě o postupu v ř́izení, zjišt'ovat jeho názor a ten reprezentovat v soudním řízení ${ }^{30}$. Zástupce může také navrhovat dưkazy a klást otázky účastníkům řízení. Má také zajišt'ovat, aby řízení představovalo pro dítě co nejmenší trauma. Nezávislý právní zástupce dítěte musí mít právní vzdělání, čímž je garantována také odborná stránka zastoupení dítěte v řízení před soudem ${ }^{31}$.

Dobrým řešení de lege ferenda by tak mohlo být zavedení samostatné nové procesní funkce (prípadně právní profese) kolizních opatrovníků dětí v řízení. Kolizní opatrovník by dle mého názoru měl mít stejně jako v Německu či Austrálii vhodné vzdělání - a to at' už právní, psychologické anebo př́padně pedagogické či sociálně právní s tím, že by měl by být schopen prokázat znalosti i ze zbývajících oborů,

23 Gesetz über das Verfahren in Familiensachen und in den Angelegenheiten der freiwilligen Gerichtsbarkeit, zákon o řízení ve věcech rodinněprávních a v záležitostech nesporného soudnictví, ze dne 17. 12. 2008 (BGBl. I s. 2586, 2587 ff), ve znění pozdějších předpisů (dále jen „FamFG“), plný text zákona dostupný z: https://www.gesetze-im-internet.de/famfg/BJNR258700008.html [cit. 2. 6. 2019].

24 ŠÍNOVÁ, Renata a kol. Řiźeni ve věcech rodinněpráuních v České republice, Slovenské republice a Nèmecku a jejich aktuální problémy. 1. vyd. Praha: Leges, s. r. o., 2010, s. 96.

25 Orig. Verfahrensbeistand.

26 ŠÍNOVÁ, Renata a kol. Řizeni ve věcech rodinnèprávnich v České republice, Slovenské republice a Nèmecku a jejich aktuální problémy. 1. vyd. Praha: Leges, s. r. o., 2010, s. 96.

27 Australský právní řád byl ke komparaci zvolen jako zástupce angloamerického právního systému. V tomto článku mimo jiné navrhuji zavedení nové procesní funkce kolizních opatrovníků, a proto jsem přesvědčena, že komparace s různými právními řády je přínosná.

28 Orig. Independent Children's Lawyers.

29 PARASHAR, Archana a Francesa DOMINELLO. The Family In Law. 1. vyd. Melbourne: Cambridge University Press, 2017, s. 295.

30 SHEEHAN, Rosemary, Allan BOROWSKI a kol. Australia's Childern's Courts Today and Tomorrow. 1. vyd. Victoria, Australie: Springer, 2013, s. 37.

31 FEHLBERG, Belinda, Rae KASPIEW, Jenni MILLBANK, Fiona KELLY a Juliet BEHRENS. Australian Family Law. The Contemporary Context. 2. vyd. Australia: Victoria, 2015, s. 21. 
např́iklad prostřednictvím speciální odborné zkoušky. Kolizní opatrovník by měl mít nejen dobré povědomí o tom, jaká má dítě práva, at' už procesní tak i hmotněprávní, ale současně by měl být schopen pracovat s dítětem s ohledem na jeho individualitu a aktuální citové rozpoložení, znát různé způsoby vedení rozhovoru, být schopen dítěti náležitě vysvětlit, co se v řízení aktuálně děje a jaké důsledky pro něj řízení má a také mu říct, jak řízení dopadlo. Je tak nepochybné, že je nezbytná nejen odborná kvalita takových osob, ale je třeba, aby byly také dostatečně empatické a měly k dětem kladný vztah. Součástí odborné zkoušky by proto mělo být dle mého názoru také psychologické posouzení předpokladů daného uchazeče vykonávat toto povolání.

Účinné zastoupení nezletilého pak samozřejmě také souvisí s možností dítěte skutečně uplatnit své právo účastnit se řízení. Pokud zde bude osoba, která bude skutečně schopna s dítětem pracovat, zjistit jeho názor, vysvětlit mu, že má právo říct před soudem, co si myslí a co si přeje a současně mu vysvětlit, že jeho přání není pro soud závazné, a že se může stát, že bude rozhodnuto odlišně, ale také, že k soudu nemusí, pokud nechce, jsem přesvědčena, že řízení bude pro dítě mnohem menší zátěž a nebude pro něj představovat pouze nějaký složitý proces, kterému nerozumí, a ve kterém se o něj rodiče hádají.

Opatrovník dítěte by pak měl být schopen také v největší možné míre prosadit respektování přání dítěte soudem při zohlednění nejlepšího zájmu dítěte. Dítě například je schopno formulovat přání, že by chtělo trvale bydlet u svých prarodičů, protože ho nenutí psát úkoly, a navíc mají na zahradě bazén. Což samozřejmě není dostatečný důvod pro svěření dítěte do péče prarodičů namísto do péče rodičů (at' už v jakékoli formě), ale opatrovník může např́klad soudu navrhnout, aby do rozsudku zakotvil, že prarodiče mají právo mít dítě u sebe vždy jeden víkend v měsíci nebo celý týden o hlavních prázdninách, nebo jiný podobný kompromis, který jednak zohlední nejlepší zájem dítěte a jednak názor a přání dítěte. Je však třeba zdůraznit, že kolizní opatrovník by na rozdíl od př́padného smluvního zástupce dítěte neměl být vázán pokyny dítěte.

Dítě má také právo za všech okolností vědět, jak řízení dopadlo a proč soud rozhodl, jak rozhodl. Vysvětlení rozsudku dítěti by také mělo být úkolem opatrovníka dítěte.

Pokud jde o samotné jmenování opatrovníka v konkrétním řízení péče soudu o nezletilé, navrhuji, aby tak činil soud jako doposud ex offo na základě \469 odst. 1 ZŘS, jen by napřriště měl být jmenován speciální kolizní opatrovník namísto OSPOD. Navrhuji, aby Ministerstvo spravedlnosti vedlo seznam kolizních opatrovníkư32 ${ }^{32}$ ze kterých by soudy mohly vybírat konkrétní osoby. Každá osoba, která bude mít zájem být zapsána v seznamu kolizních opatrovníků, by měla mít právní vzdělání a složit odbornou zkoušku jak z práva, tak také ze základů psychologie a pedagogiky. Ministerstvo spravedlnosti by mělo

32 Obdobně jako je tomu v př́padě rozhodcủ, kteří mohou rozhodovat spotřebitelské spory podle $\int 40 \mathrm{a}$ odst. 1 zákona č. 216/1994 Sb., o rozhodčím řízení a o výkonu rozhodčích nálezů, ve znění pozdějších předpisů. 
do budoucna také zajistit průběžná školení zapsaných kolizních opatrovníků. Jsem přesvědčená, že institut speciálního kolizního opatrovníka by pak byl využitelný i v dalších ř́zeních, kterých se bude účastnit nezletilé dítě, a to včetně rrízení sporných. I ve sporných řízeních musí být totiž důsledně chráněn nejlepší zájem dítěte, který mưže být nedostatečně odborným zastoupením ohrožen. K obdobnému závěru koneckonců dospěl také Ústavní soud, který ve sporných řízeních upřednostňuje zastoupení nezletilého advokátem ${ }^{33}$.

Unie rodinných advokátů $\mathrm{v}$ rámci připomínkového rrízení $\mathrm{k}$ novele občanského soudního řádu navrhla, aby procesním opatrovníkem dítěte byl vždy ustanoven advokát ${ }^{34}$. Výjimkou by pak měly dle toho návrhu být pouze řízení ve věcech rodinných, kde Unie rodinných advokátů nadále navrhuje zachovat zastoupení OSPOD. V souladu s výše uvedeným se s těmito návrhy nemohu v plném rozsahu ztotožnit. Zastoupení nezletilého advokátem by po odborné právní stránce zajisté přineslo pozitivní změnu př́slušné české legislativy. Nicméně advokát nemá pedagogické ani psychologické vzdělání a není povinen prokazovat ani základní znalosti těchto oborů, stejně jako dovednost komunikovat s dítětem s ohledem na jeho věk, rozumovou a volní vyspělost a citové rozpoložení. Zastoupení dítěte advokátem, kterého mu soud jako opatrovníka jmenuje, si proto dovedu představit jako rychlé dočasné řešení. Konečným řešením by však do budoucna mělo dle mého názoru opravdu být vytvoření nové procesní funkce specializovaných opatrovníků dítěte, kterými rozhodně mohou být také advokáti, kteří si doplní vzdělání a složí odbornou zkoušku. Jak jsem již opakovaně uvedla, s funkcí OSPOD jakožto procesního opatrovníka bych navrhovala do budoucna nepočítat ani ve sporných řízeních a ani v řízeních nesporných, at' už rodinněprávních (ve věcech péče soudu o nezletilé) nebo v jakýchkoli jiných.

\section{Interdisciplinární spolupráce - obecně}

Ř́zení ve věcech péče soudu o nezletilé by mělo být vedeno výhradně v souladu s nejlepšími zájmy dítěte, a proto by mělo probíhat bez zbytečných průtahů s důrazem na snahu dojít ke smírnému řešení problému a převzetí odpovědnosti za budoucí řešení případných konfliktů samotnými rodiči dítěte. Jedním ze způsobů, jak takové řízení vést, je pak tzv. interdisciplinární spolupráce všech profesí podílejících se na řešení rodičovského konfliktu.

Účelem interdisciplinární spolupráce je efektivnější př́stup k problémům spojených s ochranou nezletilých dětí a jejich řešení. Spočívá ve znalosti a vymezení kompetencí jednotlivých subjektů a organizací, které jsou do řešení zapojeny a v prohlubování jejich vzájemné kooperace tak, že dochází k pokud možno automatické návaznosti

33 Srov. např. Nález Ústavního soudu ze dne 19. 2. 2014, sp. zn. I. ÚS 3304/13.

34 ŠRÁMEK, Dušan. Opatrovníkem dítěte by mohl být ze zákona advokát. In: Ceskeajustice.cz. [online]. 24. 3. 2019. Dostupné z: https://www.ceska-justice.cz/2019/03/opatrovnikem-ditete-by-mohl-byt-ze-zakona-advokat/ [cit. 1. 6. 2019]. 
a propojení ${ }^{35}$. Správně aplikovaná spolupráce jednotlivých profesí pak má pomoci zejména rodičům vyřešit jejich konflikty a nalézt znovu cestu vzájemné komunikace. Díky tomu mají být rodiče do budoucna schopni rozhodovat o otázkách společného dítěte bez ingerence soudní moci. V praxi se nejvíce osvědčuje aplikace interdisciplinární spolupráce již od prvního kontaktu rodičů s úřady, nebot' to zrychluje postup a rodičům se nedává velký prostor k cílenému protahování řízení a taktizovánîîn.

\section{Tzv. Cochemská praxe}

Jedním z nejznámějších a také nejlépe popsaných modelů interdisciplinární spolupráce je tzv. Cochemská praxe, která v posledních letech nachází své místo také v českém soudnictvi ${ }^{37}$. S tímto termínem je často pojeno jméno Markéty Novákové, zakladatelky webu cochem.cz a také soudce Vladimíra Poláka z Okresního soudu v Novém Jičíně, které považuji za iniciátory zapojování tzv. „,cochemských“ principů do českého soudnictví ve věcech péče soudu o nezletilé. Přenesení know-how tzv. Cochemské praxe do českého prostředí se intenzivně od roku 2012 věnuje také Úřad pro mezinárodně právní ochranu dětíi ${ }^{38,39}$.

Historie tzv. Cochemské praxe neboli tzv. Cochemského modelu sahá do roku 1992, kdy její vznik inicioval rodinněprávní soudce Jürgen Rudolph ve spolupráci s místním orgánem péče o dítě (Jugendamt) působící v menším německém městě Cochem ${ }^{40}$. Na jejich popud se téhož roku konala tzv. Cochemská konference, které se účastnily všechny profese zapojené do řešení rodičovských konfliktů. Konference byla reakcí na špatnou společensko-právní realitu dané doby, pokud jde o otázku poměrů nezletilého dítěte v době po rozpadu vztahu jeho rodičů. Podle právní úpravy platné v Německu až do velké novely rodinného práva v roce 1998 soudy po rozvodu rodičů rozhodovaly o tom, kterému z rodičů bude dítě svěřeno do péče a současně pouze tomuto rodiči zůstala zachována všechna práva vůči dítěti. Druhému rodiči tato práva zachována nebyla ${ }^{41}$. Většina

35 BRZOBOHATÝ, Robin a kol. Interdisciplinárni spolupráce v nejlepšim zájmu dítète. Metodické doporučeni pro résení rodičovských konfliktu nejen s mezinárodnim prvkem. 1. vyd. Brno: Tribun EU, s. r. o., 2015, s. 1.

36 Ibid.

37 Prvním soudem uplatňujícím principy tzv. Cochemské praxe byl Okresní soud v Novém Jičíně. Následuje ho např́klad také Okresní soud v Přerově.

38 CIRBUSOVÁ, Martina a Romana ROGALEWICZOVÁ. Cochemská praxe - vznik a vývoj. Právo a rodina: rodina, maželství, dèti a mládeそ̌, dédictví, Linde Praha, a. s., 2015, roč. 17, č. 6, s. 11-15.

39 Bližší informace na: https://www.umpod.cz/urad/rozvoj-partnerstvi-v-oblasti-mezinarodni-spoluprace/ [cit. 2. 6. 2019].

40 FÜCHSLE-VOIGT, Traudl. Verordnete Kooperation im Familienkonflikt als Prozess der Einstellungsänderung: Theoretische Überlegungen und praktische Umsetzung. Familie Partnerschaft Recht, 2004, č. 11, s. 600 .

41 WILLUTZKI, Siegfried. Das Fam-FG in der FGG-Reform. Vortrag. Dostupné z: https://web.archive.org/ web/20121018085257/http://www.lvr.de/app/resources/vortragwillutzki_famfg_fgg_reform.pdf 
rodičů se však práv k dítěti nevzdává dobrovolně, proto tato právní úprava vedla k eskalaci konfliktů v rodině, což následně vedlo k častým rozhodnutím o tom, že se dítě nemá s druhým rodičem vůbec stýkat, anebo jen velmi omezeně, aby mělo možnost situaci zpracovat ${ }^{42}$. To pak samožrejmě vedlo k výraznému narušení vztahů mezi dítětem a druhým rodičem, v nejhorších př́padech dítě ztrácelo trvale vztah k rodiči a tudíž i možnost strávit své dětství s oběma rodiči.

Následně proto byla svolána uvedená konference v Cochemu, kde se sešli zástupci všech profesí, které se na řízení o úpravě poměrů k dítěti po rozvodu podílely, působící v obvodu zdejšího soudu pro věci rodinné. I přes prvotní neshody a převažující vzájemnou kritiku mezi jednotlivými profesemi, byla nakonec výsledkem konference shoda zúčastněných, že je nutné vytvořit propojený systém spolupráce, kdy budou jednotlivé subjekty informovány o postupech a kompetencích svých kolegů z ostatních profesí $\mathrm{s}$ tím, že pro všechny bude rozhodující jediný cíl - a to najít řešení v zájmu dítěte ${ }^{43}$. V roce 1993 pak byla prijjata Cochemská dohoda, ve které byly popsány cíle a principy tzv. Cochemské praxe, které zůstávají uplatňovány do současnosti a měly by být dle mého názoru vzorem pro funkční vedení řízení ve věcech péče soudu o nezletilé i u nás, pokud nebude z okolností v rodině zjevně vyplývat, že použití tzv. cochemských (interdisciplinárních) principů není vhodné.

\section{Principy interdisciplinární spolupráce}

Vůdčím principem interdisciplinární spolupráce je premisa, že rozhodnutí o dítěti patří primárně do rukou rodičů. Oběma rodičům náleží stejná rodičovská odpovědnost, ze které plyne také jejich odpovědnost a povinnost o dítěti rozhodovat a dohodnout se na úpravě poměrů dítěte a na otázkách, které se dítěte týkají. Výsledkem řízení proto má být dohoda, na jejímž obsahu se účastníci řízení shodnou. Lze pak totiž předpokládat, že obě strany budou schopny ji dodržovat. Tento princip pak v českých podmínkách naplňuje ustanovení $\int 474$ odst. 1 ZŘS, podle kterého soud rodiče vede ke smírnému vyřešení sporu. Vychází se z toho, že dohoda rodičů je v zásadě v souladu se zájmy dítěte a může tak být nejvíce př́nosná, a to nejen v daném okamžiku, ale i z hlediska kvality budoucích vztahů zúčastněných osob ${ }^{44}$. Upřednostnění dohody rodičů je koneckonců také v souladu se zásadou minimalizace zásahů státu do rodinného života, protože jak uzavírá Ústavní soud, stát může v souladu se zmiňovanou zásadou minimalizace zásahů

42 ROGALEWICZOVÁ, Romana. Interdisciplinární spolupráce při řešení rodičovských konfliktů. Bulletin advokacie, 2017, roč. 23, č. 12, s. 35.

43 RUDOLPH, Jürgen. Du bist mein Kind. Die „Cochemer Praxis“ - Wege zu einem menschlicheren Familienrecht. 1. vyd. Berlin: Schwarzkopf \& Schwarzkopf Verlag, GmbH, 2007, s. 40.

44 SVOBODA, Karel, Šárka TLÁŠKOVÁ, David VLÁČIL, Jiří LEVÝ, Miroslav HROMADA a kol. Zákon o zuláśtnich rízenich soudnich. Komentár. 1. vyd. Praha: C. H. Beck, 2015, s. 956. 
do práv rodičů a dětí podle čl. 32 odst. 4 Listiny základních práv a svobod zasáhnout pouze, je-li to nezbytně nutné ${ }^{45}$.

Dosažení dohody mezi rodiči pak také odpovídá snaze ušetřit dítě v největší možné míře stresu zpo̊sobenému soudním řízením a rozpadem vztahu rodičů jako takovým. Dítě mnohdy není schopno pochopit situaci mezi rodiči a může si nést trauma, že pokud se rodiče nejsou schopni dohodnout, co s ním bude, je důvodem hádek a rozpadu vztahu rodičů právě ono ${ }^{46}$. Rodič, který se nesnaží, aby jeho dítě rozpad vztahu rodičů pocítilo co nejméně, tak jedná v rozporu se zájmy dítěte. Tímto principem lze argumentovat př̀ doporučování odborné pomoci rodičům s tím, že soud považuje dobrovolnou účast na odborné pomoci za projev specifické rodičovské kompetence, tj. kompetence provést dítě rozpadem vztahu rodičů s co nejmenší újmou ${ }^{47}$.

Pro rodiče zmítané negativními emocemi způsobenými rozchodem mưže být mnohdy hledání kompromisu s druhým partnerem nepředstavitelné. Z dítěte se mnohdy snaží vytvořit spíše svou „zbraň“ proti bývalému partnerovi. Při hledání smírného řešení proto považuji za nejdůležitější snažit se rodiče přimět pohlédnout na vzniklou situaci z pohledu jejich společného dítěte. Vcítit se do toho, co asi prožívá a jak si nejspíš okolnosti vykládá, a jaké důsledky může mít způsob uspořádání poměrů do budoucna. Rodiče je proto potřeba vést $\mathrm{k}$ tomu, aby na věc nahlíželi perspektivou dítěte ${ }^{48}$. Takový pohled na věc rodičům nastaví pomyslné zrcadlo toho, jak se vlastně chovají a že zapomněli, že předmětem řízení není určení, kdo z nich je v právu, případně, kdo zavinil rozpad vztahu apod., nýbrž že jediným předmětem řízení je upravit poměry jejich dítěte v souladu s jeho zájmy. Hmotněprávní východisko tohoto principu je možné nalézt $\mathrm{v} \int 866 \mathrm{OZ}^{49}$.

Výše uvedené vede k jedinému závěru, že alfou a omegou nalezení smírného řešení mezi rodiči je odstranění konfliktní situace mezi nimi. To je také v souladu s nejlepším zájmem dítěte, protože tak jedná rodič, který je schopen oddělit svou rodičovskou roli od partnerského konfliktu. Ono je to vlastně logické. Kdyby mezi rodiči nevládla bojovná nálada, pravděpodobně by nebylo nutné je vést $\mathrm{k}$ dohodě pomocí soudního řízení.

Je však nepochybné, že vždy nemusí být v možnostech samotného soudce dovést rodiče ke smíru. To ostatně po soudci nepožaduje ani zákon, když druhá věta $\int 474$ odst. 1 ZŘS stanoví, že soud může rodičům uložit na dobu nejvýše 3 měsícú účast na mimosoudním smírčím nebo mediačním jednání nebo rodinné terapii, nebo jim nařídit setkání

\footnotetext{
45 Srov. např. Nález Ústavního soudu ze dne 15. 3. 2016, sp. zn. III. ÚS 2298/15.

46 ŠPAŇHELOVÁ, Ilona. Ditě a roẓod rodiču. 1. vyd. Praha: Grada Publishing, a. s., 2011, s. 29-30.

47 POLÁK, Vladimír a Lenka WESTPHALOVÁ. Interdisciplinární spolupráce ve věcech péče soudu o nezletilé. Právní roz̧bledy, 2018, roč. 25, č. 7, s. 240-248.

48 Ibid.

49 Ibid.
} 
s odborníkem v oboru pedopsychologie. Samotný text zákona tak předpokládá určitou formu spolupráce s jinými profesemi.

V souladu s principy tzv. Cochemské praxe je však potřeba, aby taková spolupráce probíhala podle funkčně nastavených pravidel. Postup zúčastněných institucí by měl být koordinovaný a současně je třeba uvést, že se nejedná pouze o otázky provázanosti s mimosoudními formami smírného řešení. Díky koordinaci vstupuje do řešení rodičovského „sporu“ ve správný okamžik správná profese. Jinými slovy řečeno, sladění postupu profesí vede k tomu, že se role ujímá v daný okamžik právě ta profese, která může nejvíce přispět ke zdárnému vyřešení věci. Někdy se hovoří o tzv. sesít'ování prostř̌edkư ${ }^{50}$. Všechny zúčastněné profese by zejména měly být orientovány na stejný cíl a společně se snažit naplnit vyšetřovací zásadu, která ovládá řízení ve věcech péče soudu o nezletilé. Takový postup pak také umožňuje zkrácení trvání řízení a vede k maximalizaci efektu spolupráce ${ }^{51}$. Hlavní úkolem OSPOD by měla být sociální práce s rodiči a jejich základní poučení o právech a povinnostech, o postupu v soudním řízení apod. Soudci zákon nabízí možnost využít institut tzv. jiného soudního roku (『18 ZŘS), během kterého by měl s rodiči věc probrat v neformální atmosféře, např́klad ve své kanceláři, poučit je o právní úpravě a relevantní judikatuře, zjistit jaká je situace v rodině, zda se již pokusili na něčem dohodnout a na základě takto zjištěných informací rozhodnout o dalším postupu ${ }^{52}$. Poskytovatelé doporučené odborné pomoci by měli rodičům vysvětlit dopady jejich partnerského konfliktu na dítě a pomocí mediačních technik je vést k samostatnému výkonu rodičovské odpovědnosti v souladu se zájmy dítěte ${ }^{53}$.

V rámci principů tzv. Cochemské praxe pak také nezbytně platí, že všechny profese, resp. důležitost jejich přičinění, jsou si rovny. Soud je sice jediným orgánem nadaným pravomocí o věci autoritativně rozhodnout, nicméně v kontextu společného cíle - dosáhnout smíru rodičů v zájmu nezletilého dítěte, je jeho úloha chápána naprosto rovnocenně s prací orgánu sociálně právní ochrany dětí nebo poskytovatelů odborné pomoci ${ }^{54}$.

Pokud jde o poskytovatele odborné pomoci, ráda bych na tomto místě poukázala na činnost neziskové organizace P-centrum v Olomouci, jehož součástí je také Rodinné centrum

50 POLÁK, Vladimír a Lenka WESTPHALOVÁ. Interdisciplinární spolupráce ve věcech péče soudu o nezletilé. Právní roz̧ledy, 2018, roč. 25, č. 7, s. 240-248.

51 NOVÁKOVÁ, Markéta. Představení iniciativy Cochem.cz. In: CIRBUSOVÁ, Martina a Romana ROGALEWICZOVÁ (eds.). Cochemskápraxe v Ceské republice. Sbornik prùspèvkư z konference porádané Úradem pro mezinárodnè právní ochranu dètí 14.-15. 5. 2015 v Brně. 1. vyd. Brno: Tribun EU, s. r. o., 2015, s. 19.

52 KANTU゚RKOVÁ, Libuše. Přístup českého soudce k řešení rodinněprávních sporů In: CIRBUSOVÁ, Martina a Romana ROGALEWICZOVÁ (eds.). Cochemská praxe v Ceské republice. Sborník prúspèvkư z konference porádané Úradem pro mezinárodně práuní ochranu dětí 14.-15. 5. 2015 v Brně. 1. vyd. Brno: Tribun EU, s. r. o., 2015, s. 25-26.

53 POLÁK, Vladimír a Lenka WESTPHALOVÁ. Interdisciplinární spolupráce ve věcech péče soudu o nezletilé. Prárni roz̧ledy, 2018, roč. 25, č. 7, s. 240-248.

54 Ibid. 
U Mloka a mediační centrum (dále jen „centrum“) ${ }^{55}$, u kterého jsem se setkala s velmi dobrými ohlasy z praxe. V centru je poskytována sociální služba rodinám s dětmi, které se nacházejí v nepříznivé životní situaci, přičemž nepř́iznivou situací se rozumí mimo jiné narušené vztahy a komunikace $\mathrm{v}$ rámci rodiny, nedostatečné výchovné kompetence rodičů a nevhodné prostředí pro dítě způsobené konflikty v rodině či rozpadem vztahu rodičů. Rodiny jsou $\mathrm{v}$ rámci sociálního poradenství a odborných programů vedeny k tomu, aby byly schopny vyřešit nepříznivou situaci samy. Jedním z programů je také tzv. Case management, který představuje koordinovanou spolupráci s více institucemi pro konkrétního klienta, který se jednání účastní, nejčastěji s orgánem sociálně právní ochrany dětí či pedagogicko-psychologickou poradnou. Centrum je tudíž schopno zapojit se do interdisciplinární spolupráce. Centrum rovněž zprostředkovává rodinné mediace.

Specifické postavení pak zaujímají právní zástupci rodičů - advokáti. Advokáti si mnohdy neuvědomují anebo nepřipouštějí, že se v případě řízení ve věcech péče soudu o nezletilé nejedná o klasický spor, ve kterém je možné bud' zvítězit, nebo být poraženýs6, a že tudíž není vhodné využívat útočnou strategii. Při akceptaci tzv. Cochemského modelu by i advokáti měli přistoupit na to, že budou hájit nejlepší zájem dítěte. Je to však problematická otázka hned z několika úhlů pohledu. Podle zákona o advokacii ${ }^{57}$ je advokát povinen chránit a prosazovat práva a oprávněné zájmy klienta a řídit se jeho pokyny. To neplatí pouze tehdy, pokud by to bylo $\mathrm{v}$ rozporu s právními předpisy. Advokát by se tak měl primárně orientovat na zájmy svého klienta a poslouchat jeho pokyny, které budou samozřejmě odpovídat klientově představě o budoucím uspořádání poměrů, aniž by mu byla stanovena povinnost zjišt'ovat objektivní stav věci. Je velmi pravděpodobné, že $\mathrm{v}$ zájmu dítěte bude mnohdy takové uspořádání, které neodpovídá představě klienta. Pokud by advokát tlačil svého klienta $\mathrm{k}$ přistoupení $\mathrm{k}$ dohodě s druhým rodičem, tj. k tomu, aby ustoupil ze svých představ, riskuje tím možnou ztrátu klienta. V tomto směru se vyjádřili také všichni zástupci advokátní praxe, kterých jsem se při tvorbě tohoto článku dotázala, zda je pro ně při zastupování klienta rozhodující primárně jeho pokyn, nebo zda také zkoumají, zda jeho návrhy odpovídají nejlepšímu zájmu dítěte. Dotázání advokáti s malými rozdíly odpověděli totožně. Rozhodující je pro ně odvést takovou práci, se kterou bude spokojen jejich klient s tím, že předpokládají, že on sám jako rodič ví, co je v zájmu nezletilého dítěte. Tuto kolizi mezi ochranou zájmu dítěte a zapojením advokátů by mohla vyřešit novela advokátních předpisů, zejména advokátního tarifu ${ }^{58}$,

55 Další informace dostupné z: http://www.p-centrum.cz/rodinne-centrum-u-mloka/ [cit. 2. 6. 2019].

56 ROGALEWICZOVÁ, Romana. Interdisciplinární spolupráce při řešení rodičovských konfliktů. Bulletin advokacie, 2017, roč. 23, č. 12, s. 35.

57 Srov. \ 16 zákona č. 85/1996 Sb., o advokacii, ve znění pozdějších předpisů.

58 Vyhláška Ministerstva spravedlnosti č. 177/1996 Sb., o odměnách advokátů a náhradách advokátů za poskytování právních služeb (advokátní tarif). 
po vzoru německé praxe, kdy je advokátům za zastupování v rodinněprávních sporech, které budou ukončeny dohodou rodičů stanovena paušální odměna a právní zástupci se současně zavazují k nekonfliktnímu způsobu vedení sporu ${ }^{59}$.

Poslední interdisciplinární zásadou je pak preventivní včasná intervence v konfliktech. Ta se projevuje např́klad v přesném stanovení lhůt. Klade se důraz na rychlost rrízení, kooperovaný postup tak, aby nebyl dán rodičům prostor pro uzavírání koalice s různými odborníky, manipulaci s dítětem, nekonečné podávání vyjádření, ve snaze zamezit možnosti uplatňovat útočné strategie vedení sporu apod. Navíc protahované řízení znamená také delší stresovou zátěž pro dítě.

Z výše uvedeného tak vyplývá, že uplatnění principů interdisciplinární spolupráce inspirované více než 20 let využívaným modelem tzv. Cochemské praxe by mohlo ve velkém množství řízení ve věcech péče soudu o nezletilé vést ke zefektivnění způsobu vedení těchto řízení tak, aby představovaly pokud možno co nejmenší stresovou zátěž pro dítě. Pouze řízení, které je i v souladu s Principy justice vstřícné k dětem přiměřeně rychlé a efektivní, může zabránit další eskalaci konfliktu v rodině a zamezení prostoru pro taktizování rodičů, prodlužování řízení, opakované změny výpovědí rodičů apod. Př́slušné právní předpisy (primárně OZ a ZŘS) navíc jsou dle mého názoru k uplatňování těchto principů zcela použitelné, aniž by bylo třeba rozsáhlých novel. Právní předpisy, tzv. Cochemská praxe a koneckonců i justice vstřícná k dětem jsou totiž vedeny společným ústředním motivem, kterým je ochrana nejlepšího zájmu dítěte.

\section{Závěr}

Tento článek byl věnován tématu posílení role nezletilého v řízeních péče soudu o nezletilé, které je ve světle současné společenské situace stále vysoce aktuální. Řízení ve věcech péče soudu o nezletilé se ročně týká na tisíce rodin a nezletilých dětí. Tato řízení bývají důsledkem rozpadu vztahu rodičů dítěte, což samo o sobě je pro nezletilého emočně náročná situace a soudní řízení by negativní pocity dítěte nemělo ještě více umocňovat a stresovat dítě více, než je nezbytně nutné. Článek se proto zaměřoval na otázku, v jakém postavení se dítě v řízení nachází a jaké instrumenty je možné využít k tomu, aby byl průběh řízení ve věcech péče soudu o nezletilé dítěti co nejvíce usnadněn.

Základní východisko pro dotčenou problematiku představuje čl. 3 odst. 1 Úmluvy, který stanoví, že předním hlediskem při jakékoli činnosti týkající se dětí, at' už uskutečňované veřejnými nebo soukromými zařízeními sociální péče, správními nebo zákonodárnými orgány, je nejlepší zájem dítěte. Předmětem všech řízení ve věcech péče soudu o nezletilé proto musí být výhradně zjištění, jaké uspořádání je v nejlepším zájmu dítěte. V souladu

59 NOVÁKOVÁ, Markéta. Představení iniciativy Cochem.cz. In: CIRBUSOVÁ, Martina a Romana ROGALEWICZOVÁ (eds.). Cochemská praxe v České republice. Sborník prǐspèvkè z konference poŕádané Úradem pro mez̧inárodně právni ochranu dětí 14.-15. 5. 2015 v Brně. 1. vyd. Brno: Tribun EU, s. r. o., 2015, s. 21. 
s touto premisou zákonné předpisy upřednostňují skončení řízení ve věcech péče soudu o nezletilé schválením dohody rodičů dítěte a k tomu umožňují rozhodujícímu soudci nejen poměrně neformálně pracovat s rodiči a dítětem mimo jednání během tzv. jiného soudního roku, ale lze také v průběhu řízení využít pomoci jiných profesí.

Koordinovaná spolupráce napříč různými profesemi, které se na řešení konfliktů v rodině v zájmu dítěte podílejí, se v posledních letech těší výrazné pozornosti jak médií, tak odborníků, zejména pokud jde o inspiraci v tzv. Cochemském modelu.

Uspořádání, které bude v nejlepším zájmu dítěte, je potřeba hledat při náhledu na situaci z perspektivy dítěte. Pokud na to rodiče $v$ důsledku vlastních emocí zapomenou, je třeba jim připomenout, že se rozcházejí jako partneři, avšak nikoli jako rodiče ${ }^{60}$, a proto i nadále musejí vykonávat práva a povinnosti tvořící rodičovskou odpovědnost a jednat zásadně v zájmu dítěte. Dítě má právo na kontakt a péči obou rodičů ve stejné mírée. Pro dítě je také obrovský tlak, pokud musí snášet hádky rodičů, které navíc není schopno úplně pochopit. S ohledem na dítě by se proto měli vždy snažit dosáhnout dohody.

Pokud jsou vztahy mezi rodiči vyostřené, může být nalezení dohody náročnější, než se na první pohled zdá. Rodiče mívají tendence vyřizovat si prostřednictvím dítěte účty mezi sebou, vydírají se např́klad vyloučením styku jednoho rodiče, anebo nepřiměřenými požadavky na výživné apod. Rezidentní rodič (tedy rodič, kterému bylo dítě svěřeno do výlučné péče) může dítě také poštvávat proti druhému rodiči. Taková situace $\mathrm{v}$ rodině by proto měla být $\mathrm{v}$ zájmu dítěte co nejdříve ukončena. Rodičům proto může výrazně pomoci pozitivní působení soudu a také jiných profesí, které se řízení ve věcech péče soudu o nezletilé účastní. Koordinovaná spolupráce různých profesí, vystavěna na výše popsaných principech, může pomoci rodičům uvědomit si svou rodičovskou roli a znovu vykonávat rodičovskou odpovědnost v souladu se zájmy dítěte. Odborná spolupráce tak může pomoci smírnému vyřešení věci a resp. urychlit přijetí dohody rodiči.

Právní úprava navíc použití principů tzv. Cochemské praxe umožňuje, a pro její globální aplikaci by tak nebyla potřeba žádná rozsáhlá novela právních předpisů. Upřímně proto doufám, že okresní soudy přistoupí, například po vzoru Okresního soudu v Novém Jičíně, k zavádění popsaných principů.

$\mathrm{Na}$ závěr je třeba říci, že si tento článek nekladl za cíl podrobně vyčerpat všechny související otázky. Obrovské téma k diskuzi např́iklad představuje otázka, jakou roli by měli zastávat v rrízeních péče soudu o nezletilé právní zástupci rodičů - advokáti. Jedná se však o poměrně složitou systémovou otázku, se kterou souvisí mnoho problematických bodů. Nelze opomenout, že je advokátnímu stavu přiznána poměrně široká míra samosprávy

60 NOVÁKOVÁ, Markéta. Představení iniciativy Cochem.cz. In: CIRBUSOVÁ, Martina a Romana ROGALEWICZOVÁ (eds.). Cochemská praxe v České republice. Sbornik př̌spèvkè z konference porádané Úradem pro mezinárodně právní ochranu dètí 14.-15. 5. 2015 v Brně. 1. vyd. Brno: Tribun EU, s. r. o., 2015, s. 19. 
a novely advokátních předpisů týkající se nastíněného kontextu by tak neměly probíhat bez součinnosti advokátní komory.

S posílením role nezletilého v řízeních péče soudu o nezletilé souvisí také otázka zastoupení nezletilého v průběhu takového rrízení. V této problematice spatruji obrovský nedostatek české právní úpravy. Aktuální pojetí zákona počíá s tím, že dítě má být nejčastěji zastoupeno veřejným opatrovníkem, tj. orgánem sociálně právní ochrany dětí. Výkon funkce kolizního opatrovníka, však není jediným úkolem pracovníků OSPOD, kteří pak nemají dostatečnou kapacitu na individuální práci s každým jednotlivým dítětem, které v řízení zastupují, což rozhodně není v souladu se zájmy dítěte. Proto jsem přesvědčena, že vhodným řešením de lege ferenda by mohlo být zavedení nové procesní funkce kolizních opatrovníků, kteří budou mít příslušné vzdělání (měli by se orientovat v právní úpravě a také ovládat základy psychologie a pedagogiky). 